\title{
Psychiatric Co-morbidities Among Patients of Globus Pharyngeus Attending Psychiatry Clinic of a Teaching Hospital
}

\author{
Shrestha $\mathbf{R}^{1}$, Sharma $\mathbf{B}^{1}$, Devkota $\mathbf{A}^{1}$
}

1. Lecturer, Department of Psychiatry, Lumbini Medical College E Teaching Hospital Ltd.

E-mail *Corresponding author : rajesh69411@ hotmail.com

\begin{abstract}
Introduction: Globus sensation is described as a constant feeling of a lump, something stuck or foreign body in the throat associated with an uncomfortable experience of dysphagia or choking. It is a common complaint in Ear, Nose and Throat clinics. The symptom is considered functional when no apparent organic cause is detected. In that case the symptoms must be positively identified as psychologically related to some underlying mental conflict or need. The objective of this study is to evaluate the occurrence of psychiatric Co-morbidities in patients complaining of globus sensation in throat coming to psychiatric clinic.
\end{abstract}

Material And Method: A case-control study was done. Patients coming to Outpatient of psychiatry OPD which were referred from Ear, Nose and Throat Department of Lumbini Medical College Teaching Hospital with complain of globus and not having an organic explanation of the condition were included. Age, sex and socio-economic condition matched control group was selected from healthy visitors (1st degree relatives). Mini International Neuropsychiatric Interview, English version; 5.0.0.,HAM-D/HAM-A, were applied to rule out depression, anxiety and assess psychiatric co-morbidities. Final ICD-10 Criteria were done for diagnosis which were made from two psychiatrists.

Results: About $64.28 \%(n=45)$ of globus patients had psychiatric co-morbidities which was significantly higher $(p<0.0151$, odds ratio 0.46) than their relatives attending with the patients. Major depressive disorder was found in $25.71 \%(n=18)$, Anxiety disorder in 22.85\% ( $n=16)$, Undifferentiated somatoform disorder in $7.14 \%(n=5)$, Dysthymia each in $7.14 \%(n=5)$, Psychosis in 1.4\% $(n=1)$, Personality Disorder in $1.4 \%(n=1)$.

Conclusion: Burden of psychiatric co-morbidities among the patients of globus is quiet high. So, the patient who present with Globus should undergo psychiatric evaluation after organic causes have been ruled out. They should be regularly screened for psychiatric illness and an integrated treatment approach can be taken for them.

Keywords: Psychiatric Co-morbidities, Globus Pharyngeus, Stress

\section{INTRODUCTION}

Globus is a persistent sensation of a lump, something stuck, classically a hair or crumb-like foreign body in the throat, associated with an uncomfortable experience of dysphasia or choking. The aetiology of globus remains multifactorial and unclear. Gastro-esophageal reflux, pharyngeal inflammation, cricopharyngeal spasm, sinusits and psychogenic factors remain the most common cause of globus. ${ }^{1,2}$ The symptom is considered functional when no apparent organic cause is detected. In that case the symptoms must be positively identified as psychologically related to some underlying mental conflict or need. In ICD-10, it is classified in the category of "Other Somatoform Disorders" with code of F44.8. ${ }^{3}$ In DSM-IVTR, the term 'globus' is directly not mentioned but by description it is fitting with 'Conversion Disorder' of subtype of 'With Motor Symptom or Deficit' in the broad classification of Somatoform Disorder. ${ }^{4}$ As its earlier name, globus hystericus suggests, there has been a long history of links between globus and psychological factors. It is the fourth most discriminating symptom of a somatisation disorder after vomiting, aphonia, and painful extremities. ${ }^{5}$ Harris et al, when comparing 
globus patients with other ENT patients (as a control group) found that globus patients had more severe life events in the year and less confiding relationships than controls. Social stress may thus play a role in either initiating or maintaining globus. ${ }^{6}$ It forms a large part of ENT practice and may account for about $4 \%$ of referrals to our outpatient clinics. ${ }^{7}$ It is reported to have been experienced by up to $45 \%$ of the population. ${ }^{1}$ Many believe that it is primarily a disease of female, though other studies suggest that it is equally present in both sexes. ${ }^{8}$ Preliminary treatment with anti-reflux medication in these patients, as gastroesophageal reflux is very common in developing countries, does not produce results in many of them. We have started assessment of their psychological distress as a potential cause of globus. 7,9

\section{MATERIAL AND METHOD}

This cross-sectional study was carried out in a tertiary care teaching hospital in western part of Nepal over a period of 3 months. The study protocol was approved by the Institutitional review Committee. Consecutive patients attending the ENT department with globus were identified using the diagnostic criteria proposed by Clouse and colleagues that includes at least 12 weeks (which need not be consecutive) in the preceding 12 months, complaints of (1) the persistent or intermittent sensation of a lump or foreign body in the throat, (2) occurrence of the sensation between meals, (3) absence of dysphagia and odynophagia, and (4) absence of pathologic gastroesophageal reflux, achalasia, or other motility disorder with a recognized pathologic basis such as scleroderma of the oesophagus. ${ }^{10}$ Patients were examined clinically including indirect laryngoscopy supplemented by endoscopy and rule out obvious organic abnormalities from ENT department. 70 patients were approached.

Socio-demographic data (age, sex, religion, residence, education, occupation, marital status, family type and socioeconomic status was collected in a pretested, preformed and semi structured questionnaire. Similar number $(\mathrm{N}=70)$ of age and sex matched controls were taken from the family members

attending with the patients. Cases and controls were screened for presence of psychiatric disorder using Mini International Neuropsychiatric Interview, English version; 5.0.0. Final. ICD-10 diagnosis was done by two expert psychiatrists. In statistical analysis, odds ratios were calculated by Chi Square Test and Fisher's Exact Test. Relationship between presence of psychiatric morbidity and sociodemographic variables were computed by student's $\mathrm{t}$ test for quantitative variable and chi square test for qualitative study.

\section{RESULT}

Table 1: Socio-demographic Characteristics Of the Patients

\begin{tabular}{|c|c|c|c|}
\hline \multicolumn{2}{|l|}{ Details } & \multirow{2}{*}{$\begin{array}{l}\text { Frequency } \\
42 \\
28\end{array}$} & \multirow{2}{*}{$\begin{array}{l}\text { Percantage } \\
60 \% \\
40 \%\end{array}$} \\
\hline $\begin{array}{l}\text { Age } \\
\text { (Mean age } \\
45.07 \text { ) } \\
\end{array}$ & $\begin{array}{l}<45.07 \mathrm{yrs} \\
>45.07 \mathrm{yrs}\end{array}$ & & \\
\hline Sex & $\begin{array}{l}\text { Male } \\
\text { Female }\end{array}$ & $\begin{array}{l}24 \\
46\end{array}$ & $\begin{array}{l}34.28 \% \\
65.71 \%\end{array}$ \\
\hline Religion & $\begin{array}{l}\text { Hindu } \\
\text { Muslim }\end{array}$ & $\begin{array}{l}68 \\
2 \\
\end{array}$ & $\begin{array}{l}97.14 \% \\
2.86 \%\end{array}$ \\
\hline Residence & $\begin{array}{l}\text { Rural } \\
\text { Urban }\end{array}$ & $\begin{array}{l}38 \\
32 \\
\end{array}$ & $\begin{array}{l}54.28 \% \\
45.72 \% \\
\end{array}$ \\
\hline Education & $\begin{array}{l}\text { Illiterate } \\
\text { Up to primary } \\
\text { Up to } \\
\text { secondary } \\
\text { Higher } \\
\text { secondary } \\
\text { and above }\end{array}$ & $\begin{array}{l}8 \\
23 \\
20 \\
19\end{array}$ & $\begin{array}{l}11.42 \% \\
32.85 \% \\
28.57 \% \\
27.14 \%\end{array}$ \\
\hline $\begin{array}{l}\text { Marital } \\
\text { Status }\end{array}$ & $\begin{array}{l}\text { Married } \\
\text { Unmarried }\end{array}$ & $\begin{array}{l}63 \\
7 \\
\end{array}$ & $\begin{array}{l}90 \% \\
10 \% \\
\end{array}$ \\
\hline $\begin{array}{l}\text { Family } \\
\text { Type }\end{array}$ & $\begin{array}{l}\text { Nuclear } \\
\text { Joint/Extended }\end{array}$ & $\begin{array}{l}32 \\
38\end{array}$ & $\begin{array}{l}45.71 \% \\
54.28 \%\end{array}$ \\
\hline Occupation & $\begin{array}{l}\text { Housewife } \\
\text { Service } \\
\text { Labourer } \\
\text { Farmer } \\
\text { Business }\end{array}$ & $\begin{array}{l}29 \\
12 \\
3 \\
18 \\
8 \\
\end{array}$ & $\begin{array}{l}41.42 \% \\
17.14 \% \\
4.28 \% \\
25.71 \% \\
11.4 \% \\
\end{array}$ \\
\hline $\begin{array}{l}\text { Socio- } \\
\text { economic } \\
\text { status }\end{array}$ & $\begin{array}{l}\text { Lower } \\
\text { Middle }\end{array}$ & $\begin{array}{l}16 \\
54\end{array}$ & $\begin{array}{l}22.85 \% \\
77.14 \%\end{array}$ \\
\hline
\end{tabular}


The mean age of the sample was 45.07 years and the index population was distributed equally of the both sides of the mean. Majority of the sample population were female $(65.71 \%)$, housewives $(41.42 \%)$, hindu by religion $(97.14 \%)$, from rural background (54.28\%), educated up to primary standard $(32.85 \%)$, married $(90 \%)$, from a joint family $(54.28 \%)$. Females out numbered males in cases by a ratio of 2:1 approximately.

Table 2: Correlation between sociodemographic variables and presence of psychiatric co-morbidities among globus patients $(\mathrm{N}=70)$

\begin{tabular}{|l|l|l|l|}
\hline Characters & $\begin{array}{l}\text { Psychiatric } \\
\text { Disorder } \\
\text { Present } \\
(\mathrm{n}=45)\end{array}$ & $\begin{array}{l}\text { Psychiatric } \\
\text { disorder } \\
\text { Absent } \\
(\mathrm{n}=25)\end{array}$ & $\begin{array}{l}\text { Fisher's } \\
\text { Exact test }\end{array}$ \\
\hline $\begin{array}{l}\text { Age } \\
\text { <45 years } \\
>45 \text { years }\end{array}$ & 26 & 18 & $\mathrm{p}>0.05(0.079)$ \\
\hline $\begin{array}{l}\text { Sex } \\
\text { Male }\end{array}$ & 19 & 7 & $\mathrm{p}>0.05(0.074)$ \\
Female & 13 & 14 & \\
\hline $\begin{array}{l}\text { Religion } \\
\text { Hindu } \\
\text { Muslim }\end{array}$ & 41 & 12 & $\mathrm{p}>0.05(1.0)$ \\
\hline $\begin{array}{l}\text { Residence } \\
\text { Rural } \\
\text { Urban }\end{array}$ & 1 & 24 & \\
\hline $\begin{array}{l}\text { Education } \\
\text { Up to primary } \\
\text { Above primary }\end{array}$ & 23 & 1 & $\mathrm{p}>0.05(0.803)$ \\
\hline $\begin{array}{l}\text { Marital Status } \\
\text { Married }\end{array}$ & 22 & 7 & $\mathrm{p}>0.05(0.079)$ \\
Unmarried & 18 & 15 & \\
\hline $\begin{array}{l}\text { Family Type } \\
\text { Nuclear }\end{array}$ & 18 & 15 & $\mathrm{p}>0.05(0.137)$ \\
Joint/Extended & 27 & 10 & $\mathrm{p}>0.05(0.137)$ \\
\hline $\begin{array}{l}\text { Occupation } \\
\text { House wife } \\
\text { Others }\end{array}$ & 21 & 8 & $\mathrm{p}>0.05(0.212)$ \\
\hline $\begin{array}{l}\text { S/E Status } \\
\text { Middle } \\
\text { lower }\end{array}$ & 23 & 18 & \\
\hline
\end{tabular}

Among the whole sample $(\mathrm{N}=70), 45$ patients $(64.28 \%)$ had co-morbid psychiatric disorders . But only 21 individuals (30\%) in the control group had some psychiatric morbidity. This difference of psychiatric co-morbidity between these two groups was statistically significant ( $\mathrm{p}$ $<0.00151$, odds ratio 0.46). The psychiatric disorders found among the patients of globus are major depressive disorder $(n=18,25.71 \%)$, Anxiety disorder $\quad(\mathrm{n}=16, \quad 22.85 \%)$, undifferentiated somatoform disorder $(\mathrm{n}=5$, $7.14 \%$ ), dysthymia (each $\mathrm{n}=5,7.14 \%$ ), personality disorder $(\mathrm{n}=1,1.42 \%)$.No significant association was found between presence of psychiatric morbidity and socio-demographic profile of the globus patients (Table 2). Psychiatric disorders were seen in $64.28 \%$ of globus patients. Major psychiatric disorders seen in our patients were major depressive episode $(25.71 \%)$ and anxiety disorders $(22.85 \%)$.

\section{DISCUSSION:}

Deary et. al. in their studies found that globus patients had significantly elevated psychological distress, including anxiety, low mood and somatic concern..$^{11}$ Though they did not use any specific psychiatric diagnosis, but the result was similar to our findings. Lehtinem and Puhakka found a considerably greater number of psychic disturbances in 20 globus patients than matched control and strongly supports the observations from our study. ${ }^{12}$ Thompson et. al. found three fourth of subjects seeking health care for globus were woman, peak age was middle age which supports the result of our study ${ }^{13}$ (e.g. $65.71 \%$ subjects were women with mean age of 45 years). On the other hand, Hsu et. al. found higher male to female ratio which is not supported by our study. ${ }^{9}$ In a study of globus sensation and psychopathology of men, Gale et. al. failed to find higher anxiety and depression on psychometry, compared to general medical outpatients, rather globus was associated with drug abuse, socioeconomic and educational disadvantages. ${ }^{14}$ But we did not find any association with socio-demographic status. Few studies, e.g. Moser et. al. did not report any significant association between emotional abnormalities and globus. ${ }^{15}$ Use of different scale for measuring psychiatric morbidities in different studies might be the source of disparity in results between the studies.

\section{Limitations.}

It was hospital based study with small sample size. To extrapolate the results in 
the general population a larger community based study is preferable.

\section{CONCLUSION:}

This study emphasizes that psychiatric disorders play a significant role in symptom production of Globus. Patients should be screened regularly for psychiatric comorbidities. They have suggested the need for an integrated treatment plan where pharmacological and psychotherapeutic interventions are integrated into a comprehensive bio-psychosocial approach. A combined pharmacological and psychological treatment approach should be taken in collaboration of different departments. It will improve the patients' outcome. Further research is required to know detailed effects of psychiatric co morbidities regarding etiology, course and prognosis of globus patients. We need to screen these patients for such co morbidities and develop a holistic approach for better outcome in such case.

\section{ACKNOWLEDGEMENT: None}

\section{CONFLICT OF INTEREST: None}

\section{REFERENCES:}

1. Lee BE, Kim GH. Globus pharyngeus: A review of its etiology, diagnosis and treatment. World J Gastroenterol. 2012 May;18(20):2462-71. doi: 10.3748/wjg.v18.i20.2462.

2. Mitchell S, Olaleye O, Weller M. Review: Current Trends in the Diagnosis and Management of Globus Pharyngeus. International Journal of Otolaryngology and Head \& Neck Surgery. 2012;1(3):57-62. doi: 10.4236/ijohns.2012.13013.

3. World Health Organization, The ICD-10 Classification of Mental and Behavioral Disorders. World Health Organization, Geneva, 1993.

4. Diagnostic and Statistical Manual of Mental Disorders. 4th ed. Text Revision. Washington, DC: American Psychiatric Association, 2000.

5. Shiomi Y, Oda N, Shiomi Y, Hosoda S. Hyperviscoelasticity of epipharyngeal mucus may induce globus pharyngis. Annals of Otology, Rhinology and Laryngology. 2002;111(12):11161119.

6. Harris MB, Deary IJ, Wilson JA. Life events and difficulties in relation to the onset of globus pharyngis. Journal of Psychosomatic Research. 1996;40(6):603-615.

7. Moloy PJ, Charter R. The globus symptom. Incidence, therapeutic response, and age and sex relationships. Archives

of Otolaryngology. 1982;108(11):740-744.

8. Zulkefly NS, Baharudin R. Using the 12-item General Health Questionnaire (GHQ-12) to Assess the Psychological Health of Malaysian College Students. Global Journal of Health Science. 2010;2(1):73-8. doi: 10.5539/gjhs.v2n1p73.

9. Hsu C.C., Wan S.J., Chou K.S. et. al. - Globus Hystericus -Reports on 25 ENT Cases and Literature Review. Zhonghua Yi Xue Za Zhi (Taipei). 43:213216, 1989

10. Clouse R.E., Richter J.E., Heading Janssens R.C. et. al. - Funcational Esophageal Disorders. GUT. 45:1131-1136, 1999.

11. Deary I.J., Smart A., Wilson J.A. - Depression and 'hassles' in globus pharyngis. Br J Psychiatry. 161:115-117, 1992.

12. Lehtinem V., Puhakka H. - A Psychosomatic Approach to the Globus Hystericus Syndrome. Acta Psychiatr Scand. 53:21-28, 1976.Thompson W.G.,

13. Heaton K.W. - Heartburn and Globus in Healthy People. Can Med Asso J. 126:46- 48, 1982.

14. Gale C.R., Wilson J.A., Dreary I.J. - Globus Sensation and Psychopathology in Men: The Vietnam Experience Study. Psychosom Medicine. 71:1026-1031, 2009.

15. Moser G., Wenzel-Abatzi T., Stelzeneder M. et. al. - Globus Sensation, Pharyngoesophageal Function, Psychometric and Psychiatric Finding and Follow Up in 88 Patients. Arch Intern Med. 158:1365-1373, 1998. 